turbidimeter. Hence the complete mineral analysis was accomplished by rapid methods.

3. A well water from Western New York.

Data. Hardness 485 , Alkalinity $186, \mathrm{Cl}_{4} 8, \mathrm{SO}_{3} 213, \mathrm{~N}$ as nitrate 7.5 . Fixed solids 682. Total calcium 348. Hence total magnesium is equivalent to 137 of calcium carbonate, $(485-348)$.

Calculating in practically the same manner as before, as it happens, we arrive at the result:

$\mathrm{CaCO}_{3}$ I86, $\mathrm{CaSO}_{4} 224, \mathrm{MgSO}_{+}$I25, $\mathrm{Mg}\left(\mathrm{NO}_{3}\right)_{2}$ 39, $\mathrm{NaCl} 80, \mathrm{SiO}_{2}$ atd $\mathrm{Al}_{2} \mathrm{O}_{3} 28$ (by difference).

\title{
Conclusion.
}

In resume it may be said that the method is admirably suited for the routine analysis of large numbers of samples, may be considered accurate to two parts per million, is applicable to all quantities of calcium including that of sea water, is equally accurate with large and small quantities of calcium, furnishes, in combination with the soap method, a rapid method of determining the total magnesium, and hence is extremely valuable in the rapid analysis of mineral and boiler waters.

MT. PROSPECT LABORATORY,

DEPT. WatyR StPPLY, Gas AND

ELsctricity, N.Y. City, Dec. 27, 06.

\section{THE RECOVERY OF ALBUMINOID AMMONIA FROM DISTILLATES CONTAMINATED WITH PERMANGANATE.}

BY F. E. HALE.

Received May 22, 1907.

In the distillation of albuminoid ammonia in sanitary water analysis it frequently happens that bumping occurs and permanganate is washed over into the distillate. Usually this happens with a hard water, or is occasioned by the use of alkaline permanganate the alkali of which contains considerable carbonate. Consequently it may usually be prevented by care in selecting for the permanganate solution only alkali containing less than five percent of carbonate and by taking care in the preparation of the alkaline permanganate solution to pour it into the retaining bottle as soon as sufficiently cool after boiling off the ammonia. The easiest remedy, when bumping has occurred, is to distill a second portion of the water which is being analyzed, but occasionally this is impossible from lack of sufficient water and a method of recovery from the distillate seems to be worthy of description.

The method, which is entirely of a chemical nature, consists in reducing the permanganate by an alkaline sulphite solution, oxidizing the manganous salt to the hydrated peroxide, filtering off the manganese on 
a carefully washed filter paper, nesslerizing the filtrate, and reading in the usual manner.

The alkaline sulphite solution contains $35^{\circ}$ grms. potassium hyclroxile to the liter, free from ammonia, and may be so made by boiling. It also contains 30 grms. sodium sulphite, $\mathrm{Na}_{2} \mathrm{SO}_{3} .7 \mathrm{H}_{2} \mathrm{O}$, as determined by titration with permanganate. The st1phite was found to be free from annmonia and for that reason, as well as for its reaction with permanganate in the cold, it was chosen instead of oxalic acid.

Hyclrogen peroxicle was tried in the reoxiclation of the manganese but failed to meet the requirements of the process, and the simplest and best way was found to be merely leaving the solution exposed to the air over night, at least for several hours, until the manganese was completely reoxiclized, as shown by the appearance of the brown precipitate and the absence of any green color in the solution.

Schleicher and Schüll's I $2 \mathrm{~cm}$. folded filters No. 588 were found to be more readily washed free from ammonia than ashless filters.

'Two things are essential to the process. Every trace of manganese must be removed from the distillate, as it gives a color with Nessler solution comparable with that of ammonia. Not a trace of anmonia must be introduced or removed from the distillate. The methor in cletail is as follows :

To the distillate add I cc. of the alkaline sulphite solution, rotate, and allow to stand over night exposed to the air. Freshly wash a Schleicher and Schïll small folded filter until free from ammonia. This requires jo to $100 \mathrm{cc}$, of redistilled water. The filter should be washed just before using, as a wet filter takes up ammonia from the air quite rapidly. Filter off the manganese hydrated peroxide and pour the filtrate through a second time into a fresh tube. Wash the tubes and filter paper with a very little redistilled water (not over $10 \mathrm{cc}$. is necessary), nesslerize and reat. The wash water must necessarily be guite free from ammonia.

The theoretical and practical tests of the process have been very satisfactor:- A solution of ammonium chloricle was macle up of standard strength; that is, each cubic centimeter contained o.or mgrm. of nitrogen. Of this solution varying quantities were taken, I cc., $2 \mathrm{cc}$, $3 \mathrm{cc}$., $5 \mathrm{cc}$., 8 cc., Io $\mathrm{cc}$., and $20 \mathrm{cc}$., and diluted to $50 \mathrm{cc}$., in nessler tubes. To one set was added alkaline permanganate to a strong coloration and then the permanganate was removed by the method described and the ammonia determined. These values were compared with those obtained by direct nesslerization of a second set without permanganate, all comparisons being marle with a set of permanent standards. The following table gives the arerage of several sets of results: 


$\begin{array}{cccc}\begin{array}{c}\text { Ammonium chloride } \\ \text { Solution taken. }\end{array} & \begin{array}{c}\text { Theoretical } \\ \text { Value. } \\ \text { cc. }\end{array} & \begin{array}{c}\text { Determination } \\ \text { in blank }\end{array} & \begin{array}{c}\text { Treated } \\ \text { solution. } \\ \text { mgrm. N. }\end{array} \\ \text { I } & 0.010 & 0.010 & 0.010 \\ 2 & 0.020 & 0.017 & 0.016 \\ 3 & 0.030 & 0.027 & 0.030 \\ 5 & 0.050 & 0.046 & 0.049 \\ 8 & 0.080 & 0.08 \mathrm{r} & 0.077 \\ \text { I0 } & 0.100 & 0.095 & 0.095 \\ 20 & 0.200 & 0.206 & 0.198\end{array}$

The following are a series of results, extending over several years, obtained from distillates into which permanganate had been washed because of bumping. The original sulphite solution has kept well and has been in use during this time. The figures in parentheses were recovered by this process. The results are expressed in decimal parts of $0.01 \mathrm{mgrm}$.

$\begin{array}{lcccccccccc}\text { rube. } & \text { I } & 2 & 3 & 4 & 5 & 6 & 7 & 8 & 9 & \text { 10 } \\ \text { Ist. } & 0.5 & 2.6 & \text { I.4 } & \text { I.I } & 2.8 & 2.5 & 2.4 & \text { I.7 } & \text { I.9 } & \text { I.9 } \\ \text { 2nd, } & 0.3 & 0.8 & 0.7 & 0.6 & (1.2) & (1.1) & 1.3 & 0.9 & (0.9) & (0.9) \\ \text { 3rd. } & 0.2 & 0.6 & 0.4 & 0.4 & 0.6 & (0.7) & 0.8 & (0.7) & (0.6) & (0.4) \\ \text { 4th. } & 0.2 & (0.4) & 0.2 & 0.2 & 0.5 & (0.6) & (0.6) & (0.3) & (0.4) & (0.3) \\ \text { 5th. } & (0.2) & 0.4 & (0.1) & (0.1) & 0.4 & 0.4 & 0.5 & 0.2 & 0.4 & 0.2\end{array}$

$\begin{array}{lcccccccc} & \text { II } & \text { I2 } & \text { 13 I. } & \text { I3 F. } & \text { 14 I. } & \text { 14 F. } & \text { 15 R. } & \text { I5 } \\ \text { Ist. } & 2.4 & \text { 2. I } & 2.3 & \text { I.5 } & \text { I.6 } & \text { I.2 } & \text { I.8 } & (\text { I.7) } \\ \text { 2nd. } & (\text { I.2 }) & \text { I.0 } & 0.9 & (0.5) & 0.8 & (0.7) & 0.8 & (0.8) \\ \text { 3rd. } & 0.8 & 0.7 & 0.6 & (0.4) & (0.5) & 0.5 & 0.5 & (0.5) \\ \text { 4th. } & 0.5 & (0.3) & 0.4 & 0.4 & (0.3) & 0.4 & 0.4 & \\ \text { 5th. } & (0.4) & 0.3 & 0.3 & 0.3 & 0.3 & 0.3 & 0.3 & \end{array}$

16

Free Ammonia.

Ist.
2nd
$3^{\text {rd }}$.
$4^{\text {th }}$.
$5^{\text {th }}$
$(0.6)$

$(0.1)$

$(0.0)$
Alb. Ammonia.

$$
\begin{gathered}
(3.2) \\
(1.2) \\
0.8 \\
0.4
\end{gathered}
$$$$
0.2
$$

17

Free Ammonia.

Alb. Ammonia

$$
\begin{aligned}
& (1.4) \\
& (0.6) \\
& (0.1)
\end{aligned}
$$

I. I

0.4

0.3

Analyses No. I3 and No. 14 give a comparison between figures obtained from unfiltered and filtered water. Analysis No. I5 is interesting because it compares figures obtained by repeating the distillation with recovered figures. Analyses No. I6 and No. I7 are interesting because they include all the free ammonia and the highest figures of the albuminoid ammonia. The recovery was rendered necessary by the breaking of a distilling flask and the deluging of the tubes with permanganate. 